\title{
DETERMINAN PENGAMBILAN KEPUTUSAN DALAM PEMBERIAN OPINI AUDIT
}

\author{
Lupi Susanti \\ Ardiani Ika Sulistyawati \\ Universitas Semarang \\ ardiani.ika2005@gmail.com
}

\begin{abstract}
ABSTRAK
Penelitian ini bertujuan untuk mengetahui tentang pengaruh etika profesi, komitmen profesional, pengalaman kerja, independensi audit, fee audit terhadap pengambilan keputusan untuk memberikan opini audit (studi empiris pada kantor akuntan publik di Jawa Tengah). Opini audit adalah pernyataan auditor terhadap kewajaran laporan keuangan dari entitas yang telah diaudit. Responden dalam penelitian ini adalah auditor yang bekerja pada kantor akuntan publik di Jawa Tengah. Responden dalam penelitian ini sebanyak 59 responden. Data dalam penelitian ini menggunakan data primer yang diperoleh dengan menyebar kuesioner pada kantor akuntan publik di Jawa Tengah. Metode aipengumpulan data adalah metode purposive sampling. Metode analisis yang digunakan adalah metode regresi linear berganda. Hasil penelitian ini menunjukkan etika profesi, komitmen profesional, independensi audit tidak berpengaruh terhadap pengambilan keputusan untuk memberikan opini audit. Sedangkan pengalaman kerja dan fee audit menunjukkan hasil berpengaruh terhadap pengambilan keputusan untuk memberikan opini audit.

Kata Kunci : etika profesi, komitmen profesional, pengalaman kerja, independensi audit, fee audit, opini audit
\end{abstract}

\begin{abstract}
This study aims to find out about the influence of professional ethics, professional commitment, work experience, the independence of the audit, the audit fee to the decision to provide an audit opinion (empirical studies on public accounting firms in Central Java). Auditor's audit opinion is a statement against the fairness of the financial statements from the audited entity. Respondents in this study are the auditors who work in public accountant office in Central Java. Respondents in this study were 59 respondents. The data in this study used primary data obtained by spreading the questionnaire in public accountant office in Central Java. Methods of data collection are purposive sampling method. The use of analytical method is multiple linear regression method. The results of this study showed professional ethics, professional commitment, and independence of the audit did not affect the decision to provide an audit opinion. Meanwhile, work experience and audit fees shows the results influence the decision to provide an audit opinion.
\end{abstract}

Keywords: professional ethics, professional commitment, work experience, the independence of the audit, the audit fees, audit opinion 


\section{PENDAHULUAN}

Saat ini, kebutuhan akan laporan keuangan tidak lagi hanya disediakan untuk manejemen dan bankir, namun telah meluas ke pihak-pihak lain seperti pemerintah dan pemegang saham. Oleh karena itu, perusahaan harus membuat laporan keuangan yang transparan, akurat, tepat waktu, dan tidak menyimpang dari standar akuntansi keuangan atau prinsip akuntansi yang diterima umum. Permasalahan timbul saat laporan keuangan yang disajikan oleh manajemen masih diragukan keabsahannya (Purwanti dan Sumartono, 2014). Laporan audit menjadi tanggung jawab auditor karena pada laporan audit diungkapkan berbagai temuan yang diperoleh auditor selama menjalankan tugasnya dan berisi informasi-informasi yang diperoleh auditor selaam proses evaluasi bukti transaksi sampai kesimpulan yang diperolehnya (Tamtomo, 2008) dalam (Rharasati dan Suputra, 2013).

Opini audit adalah pernyataan auditor terhadap kewajaran laporan keuangan dari entitas yang telah diaudit. Kewajaran ini menyangkut materialitas, posisi keuangan, dan arus kas. Menurut SPAP (Standar Profesional Akuntan Publik), opini audit ada 5 macam, yaitu pendapat wajar tanpa pengecualian, pendapat wajar tanpa pengecualian dengan tambahan bahasa penjelasan yang ditambahkan dalam laporan audit bentuk baku, pendapat wajar dengan pengecualian, pendapat tidak wajar, dan pendapat tidak memberikan pendapat. Opini yang paling baik adalah wajar tanpa pengecualian (unqualified opinion).

LSM Gerakan Berantas Korupsi (Gebrak) dan KP2KKN Jawa Tengah pada Kamis 07 Juni 2012, mendatangi kantor BPK Jawa Tengah yang bertujuan untuk menanyakan terkait opini BPK RI Perwakilan Jateng terhadap Laporan Keuangan APBD Kabupaten Brebes tahun 2011 yang sebelumnya berpendapat disclaimer opinion berubah menjadi Wajar dengan Pengecualian (WDP). Pada laporan hasil pemeriksaan BPK RI atas laporan keuangan Daerah Brebes tahun 2011 adalah tidak menyatakan pendapat (Disclaimer). Sedangkan resume hasil pemeriksaan atas pengendalian internal diantaranya pada penyajian aset tetap di neraca per 31 Desember 2011 tidak dapat diyakini kewajarannya. Dengan adanya kasus tersebut dalam memberikan opini audit harus lebih berhati-hati lagi dan sikap independensi harus dimiliki oleh seorang auditor (Pantura News, 2012). Berdasarkan latar belakang masalah tersebut, maka dapat dibuat masalah penelitan sebagai berikut:

1. Apakah etika profesi berpengaruh terhadap pengambilan keputusan untuk memberikan opini audit pada KAP di Jawa Tengah?

2. Apakah komitmen profesional berpengaruh terhadap pengambilan keputusan untuk memberikan opini audit pada KAP di Jawa Tengah?

3. Apakah pengalaman kerja berpengaruh terhadap pengambilan keputusan untuk memberikan opini audit pada KAP di Jawa Tengah?

4. Apakah independensi audit berpengaruh terhadap pengambilan keputusan untuk memberikan opini audit pada KAP di Jawa Tengah?

5. Apakah fee audit berpengaruh terhadap pengambilan keputusan untuk memberikan opini audit pada KAP di Jawa Tengah?

TELAAH PUSTAKA

Hubungan Logis Antar Variabel dan Perumusan Hipotesis

Pengaruh Etika Profesi Terhadap Pengambilan Keputusan Untuk Memberikan Opini Audit

Menurut Sukmawati, dkk (2014), etika profesi merupakan faktor organisasional yang akan mempengaruhi kinerja seorang auditor. Seorang auditor wajib memegang teguh aturan etika profesi yang berlaku. Pemahaman tentang etika profesi akan mengarahkan sikap dan perilaku auditor dalam melaksanakan tugas, yaitu pengambilan keputusan yang benar dalam memberikan opini tentang wajar atau tidaknya suatu laporan keuangan, karena opini yang dikeluarkan oleh auditor akan digunakan para pengguna informasi keuangan. Sukmawati, dkk (2014) dalam penelitiannya menujukkan hasil bahwa etika profesi berpengaruh positif dan signifikan terhadap opini audit. Menurut Pratiwi dan Januarti (2013) pada penelitiannya menunjukkan hasil berpengaruh terhadap pemberian opini. Menurut Rharasati dan Suputra (2013) dalam penelitiannya juga 
menunjukkan hasil berpengaruh positif terhadap pengambilan keputusan memberikan opini audit.

Dalam penelitian Suraida (2005) dalam Rharasati dan Suputra (2013) menunjukkan hasil bahwa etika berpengaruh positif terhadap ketepatan pemberian opini akuntan publik baik secara parsial maupun simultan. Penelitian yang dilakukan Saryanti (2007) dalam Rharasati dan Suputra (2013) juga menunjukkan bahwa etika profesi berpengaruh signifikan terhadap pengambilan keputusan auditor. Dalam penelitian Sabrina dan Indira (2011) dalam Rharasati dan Suputra (2013) mendapatkan kesimpulan yang berbeda, bahwa etika tidak berpengaruh terhadap ketepatan pemberian opini. Sehingga dapat dirumuskan hipotesis sebagai berikut:

$\mathrm{H}_{1}$ : Etika profesi auditor berpengaruh terhadap pengambilan keputusan untuk memberikan opini audit.

\section{Pengaruh Komitmen Profesional Profesi Terhadap Pengambilan Keputusan Untuk Memberikan Opini Audit}

Menurut Boynton et.al (2002), untuk menjalankan prinsip-prinsip ini diperlukan komitmen yang teguh agar menjadi perilaku yang terhormat, bahkan dengan mengorbankan keuntungan pribadi. Sehingga dengan komitmen profesional yang kuat, akuntan publik akan menjalankan prinsip-prinsip dalam kode etik, dan memiliki orientasi perilaku kepada kepentingan publik serta akan menghindari perilaku tidak etis yang dapat menghancurkan profesi. Komitmen terhadap suatu profesi yang tinggi akan berpengaruh terhadap kualitas audit yaitu memberikan opini yang tepat, dimana seseorang yang memiliki komitmen profesional yang tinggi akan selalu berbuat yang baik dan benar demi menjaga profesinya dalam suatu kantor akuntan publik.

Menurut Utami,dkk (2007) dalam Rharasati dan Suputra (2013) dalam penelitiannya menyebutkan bahwa komitmen profesional berpengaruh positif terhadap respon akuntan publik dalam situasi konflik dengan kesadaran etis sebagai variabel pemoderasi, dimana kesadaran etis sangat penting dalam proses pengambilan keputusan karena merupakan sumber dari proses berpikir. Menurut Abdurahman dan Nur Laila (2011) dalam Rharasati dan Suputra (2013) juga sependapat, dimana penelitiannya menunjukkan bahwa komitmen profesional berpengaruh positif terhadap pengambilan keputusan etis.

$\mathrm{H}_{2}$ : Komitmen profesional auditor berpengaruh terhadap pengambilan keputusan untuk memberikan opini audit.

\section{Pengaruh Pengalaman Kerja Profesi Terhadap Pengambilan Keputusan Untuk Memberikan Opini Audit}

Pengalaman audit adalah pengalaman auditor dalam melakukan audit laporan keuangan baik dari segi lamanya waktu maupun banyaknya penugasan yang pernah ditangani (Suraida, 2005) dalam (Rharasati dan Suputra, 2013). Pengalaman kerja merupakan hal yang sangat penting bagi seorang akuntan publik, karena seorang auditor yang mempunyai pengalaman kerja di bidang auditing yang cukup lama memiliki pengetahuan yang lebih atas pekerjaannya, dan memiliki berbagai penemuan - penemuan dalam setiap pemeriksaannya sehingga dapat mempengaruhi pengambilan keputusan untuk memberikan opini yang tepat (Rharasati dan Suputra, 2013). Penelitian Suraida (2005) dan Wijaya Kusuma (2011) dalam (Rharasati dan Suputra, 2013) menunjukkan hasil penelitian bahwa pengalaman kerja berpengaruh positif terhadap ketepatan pemberian opini, namun (Sabrina dan Indira, 2011) dalam (Rharasati dan Suputra, 2013) dalam penelitiannya menyebutkan bahwa pengalaman tidak berpengaruh langsung terhadap ketepatan pemberian opini. Auditor yang berpengalaman akan menemukan lebih banyak kesalahan pada item-item yang diperiksa dibandingkan dengan auditor yang kurang berpengalaman. Menurut Rhararasati dan Suputra (2013), pengalaman kerja berpengaruh positif terhadap pengambilan keputusan untuk memberikan opini audit. Hal ini berbeda dengan penelitian Pratiwi dan Januarti (2013) yang menunjukkan hasil bahwa pengalaman kerja tidak berpengaruh terhadap pemberian opini. 
$\mathrm{H}_{3}$ : Pengalaman kerja auditor berpengaruh terhadap pengambilan keputusan untuk memberikan opini audit.

\section{Pengaruh Independensi Profesi Terhadap Pengambilan Keputusan Untuk Memberikan Opini Audit \\ Independensi berarti sikap mental} dari pengaruh, tidak dikendalikan oleh pihak lain, tidak bergantung pada orang lain. Independensi juga berarti adanya kejujuran diri auditor dalam pertimbangan fakta dan adanya pertimbangan objektif tidak memihak dalam diri auditor dalam merumuskan dan menyatakan pendapatnya (Purwanti dan Sumartono, 2014). Menurut Mayangsari (2003), auditor yang independen cenderung benar dalam memberikan pendapat dibandingkan dengan auditor yang tidak independen. Oleh karena itu independensi sangat dibutuhkan bagi auditor karena dengan kejujuran dalam mempertimbangkan fakta dan pertimbangan yang obyektif tidak memihak, auditor dapat merumuskan dan memberikan pendapat dengan tepat. Hasil riset Tamtomo (2008) dan Kusuma (2011) dalam Rharasati dan Suputra (2013), Zy'amah (2009), Siregar (2012) serta Swari dan Ramantha (2013) membuktikan bahwa independensi berpengaruh terhadap proses pengambilan keputusan pemberian opini auditor. Kemudian riset Rharasati dan Suputra (2013) menunjukkan hasil independensi berpengaruh negatf terhadap pengambilan keputusan untuk memberikan opini audit. Namun Purwanti dan Sumartono (2014) membuktikan bahwa independensi berpengaruh terhadap ketepatan pemberian opini.

$\mathrm{H}_{4}$ : Independensi auditor berpengaruh terhadap pengambilan keputusan untuk memberikan opini audit.

\section{Pengaruh Fee Audit Profesi Terhadap Pengambilan Keputusan Untuk Memberikan Opini Audit \\ Menurut Hoitash et al (2007) dalam} Pratistha dan Widhiyani (2014), menemukan bukti bahwa ketika auditor melakukan negosiasi dengan pihak manajemen mengenai besaran tarif fee yang dibayarkan terkait hasil kerja laporan auditan, maka kemungkinan besar akan terjadi konsensi resiprokal yang jelas akan mereduksi kualitas laporan auditan. Elder (2011) dalam Pratistha dan Widhiyani (2014) menyatakan bahwa imbalan jasa audit atas kontrak kerja audit merefleksikan nilai wajar pekerjaan yang dilakukan dan secara khusus auditor harus menghindari ketergantungan ekonomi tanpa batas pada pendapatan dari setiap klien.

Fee audit dapat mempengaruhi seorang auditor untuk mengambil keputusan dalam memberikan opini audit. Fee yang diberikan oleh klien harus sesuai dengan pekerjaan yang diberikan oleh klien, jangan sampai ada fee bersyarat dalam audit. Menurut Kasidi (2007), biaya jasa audit yang besar dapat mempengaruhi independensi auditor, dengan alasan: (1) kantor akuntan publik yang menerima audit fee yang besar merasa tergantung pada klien, meskipun laporan keuangan klien mungkin tidak sesuai dengan prinsip akuntansi berterima umum; (2) kantor akuntan publik yang menerima audit fee yang besar dari seorang klien takut kehilangan klien.

$\mathrm{H}_{5}$ : Fee Audit berpengaruh terhadap pengambilan keputusan untuk memberikan opini audit. 


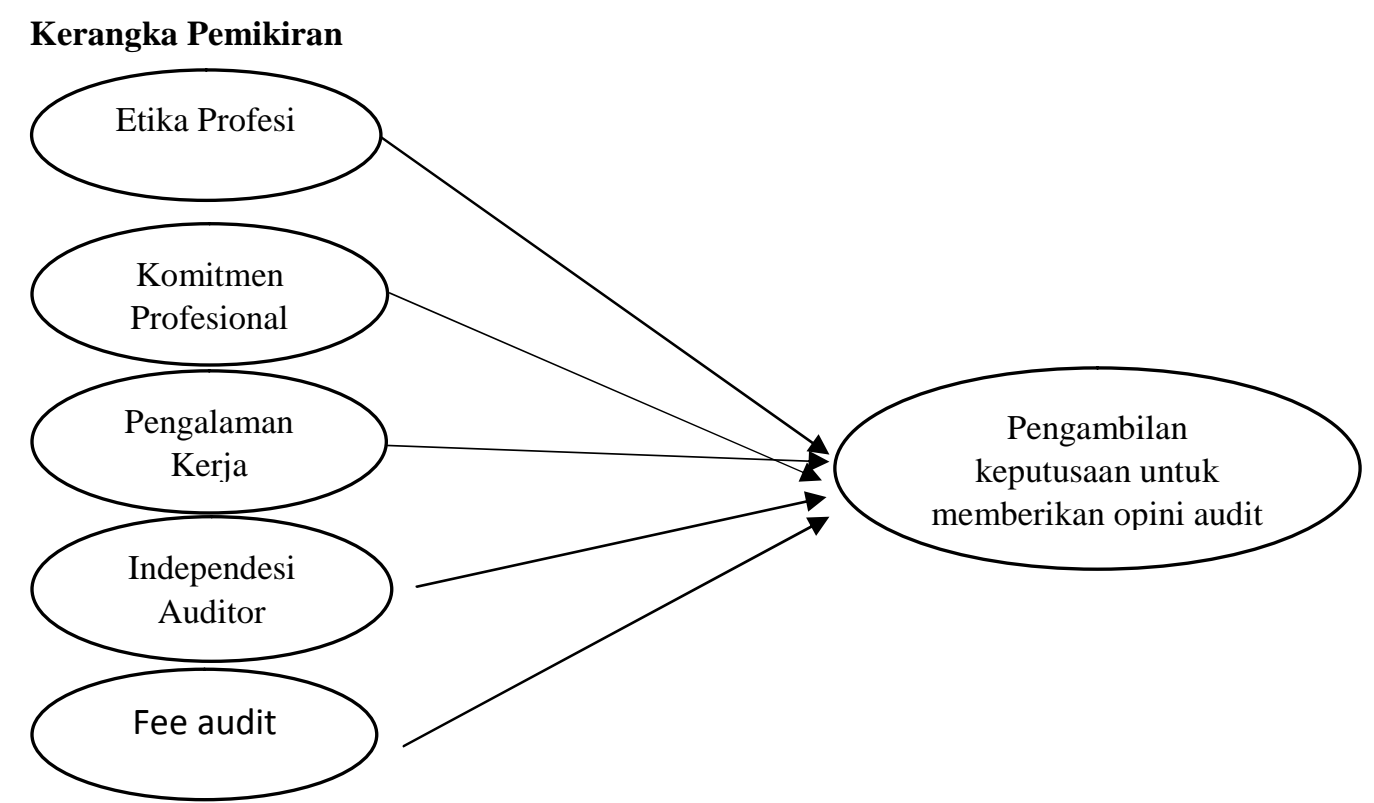

\section{METODE PENELITIAN}

Populasi dalam penelitian ini auditor yang bekerja pada KAP di Jawa Tengah. Metode yang digunakan peneliti dalam pemilihan sampel penelitian adalah (purposive sampling) dengan kriteria (1) Auditor yang sudah melakukan pekerjaaan audit minimal 1 tahun dan (2) Bukan merupakan auditor magang. Penelitian ini menggunakan data primer. Dimana data primer diperoleh dari hasil kuesioner yang berhubungan dengan penelitian. Kuesioner merupakan penelitian dengan cara mengajukan daftar pertanyaan langsung kepada responden, yaitu auditor yang bekerja pada KAP di Jawa Tengah. Skala yang digunakan adalah skala likert untuk mengukur sikap, pendapat, dan persepsi seseorang tentang kejadian atau gejala sosial. Kategori dari penilaian skala likert:

$\begin{array}{ll}\text { SS } & =\text { Sangat Setuju } \\ & \text { Diberi skor 5 } \\ \text { = Setuju } \\ \mathrm{S} & \text { Diberi skor } 4 \\ \mathrm{~N} & =\text { Netral } \\ & \text { Diberi skor } 3 \\ \mathrm{TS} & =\text { Tidak Setuju } \\ & \text { Diberi skor } 2 \\ \mathrm{STS} & =\text { Sangat Tidak Setuju } \\ & \text { Diberi skor 1 } \\ \text { Metode } & \text { analisis yang digunat }\end{array}$

Metode analisis yang digunakan adalah uji instrumen yang terdiri dari uji validitas dan uji realibilitas selanjutnya dilakuan uji asumsi klasik yang terdiri dari uji normalitas, uji multikolinearitas dan uji heteroskedastisitas. Langkah selanjutnya analisis regresi linear berganda yang bertujuan untuk mengetahui pengaruh variabel bebas terhadap variabel terikatnya. Model regresi linear berganda ditunjukkan oleh persamaan regresi berikut :

$\hat{Y}=\alpha+\beta_{1} X_{1}+\beta_{2} X_{2}+\beta_{3} X_{3}+\beta_{4} X_{4}+\beta 5 X 5+e$

Keterangan:

$\hat{Y}=$ pengambilan keputusan untuk memberikan opini audit

$\alpha=$ konstanta

$\beta_{1}-\beta_{3}=$ koefisien regresi variabel X1-X3

$\mathrm{X}_{1}=$ etika profesi

$\mathrm{X}_{2}=$ komitmen profesional

$\mathrm{X}_{3}=$ pengalaman kerja

$\mathrm{X}_{4}=$ independensi

$\mathrm{X}_{5}=$ fee audit

$\mathrm{e}=$ error

Selanjutnya dilakukan uji statistik t untuk mengetahui apakah variabel bebas yang terdapat dalam penelitian ini secara individu berpengaruh terhadap variabel terikatnya yaitu pengambilan keputusan untuk memberikan opini audit. Dilakukan juga uji statistik $F$ yang bertujuan untuk mengetahui apakah semua variabel bebas yang dimasukkan dalam model mempunyai pengaruh secara bersama-sama terhadap variabel terikat (Imam Ghozalli, 2009).

\section{HASIL DAN PEMBAHASAN}


Hasil uji validitas menunjukkan bahwa bahwa masing-masing indikator memiliki nilai koefisien korelasi yang lebih besar dari 0,2162 dan nilai signifikansi di

bawah 0,005, maka dapat disimpulkan bahwa uji validitas adalah valid. Selanjutnya dilakukan uji reliabilitas.

Tabel 1

Hasil Uji Reliabilitas

\begin{tabular}{|l|l|l|}
\hline Variabel & Cronbach Alpha & Keterangan \\
\hline Etika profesi (X1) & 0,928 & \\
\hline Komitmen profesional (X2) & 0,916 & Reliabel \\
\hline Pengalaman kerja (X3) & 0,606 & Reliabel \\
\hline Independensi audit (X4) & 0,809 & Reliabel \\
\hline Fee Audit (X5) & 0,825 & Reliabel \\
\hline $\begin{array}{l}\text { Pengambilan keputusan untuk } \\
\text { memberikan opini audit (Y) }\end{array}$ & 0,842 & Reliabel \\
\hline
\end{tabular}

Sumber : Data primer yang diolah, 2015

Berdasarkan tabel 1 dapat diketahui bahwa masing-masing variabel memiliki Cronbach Alpha lebih besar 0,60 sehingga pertanyaan dalam setiap variabel adalah reliabel. Kemudian dilanjutkan uji normalitas dengan menggunakan grafik normal plot dimana hasilnya menunjukkan titik-titik menyebar di sekitar garis diagonal dan mengikuti arah garis diagonal, maka model regresi memenuhi asumsi normalitas atau data dikatakan normal. Uji normalitas dengan grafik dapat menyesatkan kalau tidak hati-hati secara visual kelihatan normal, padahal secara statistik bisa sebaliknya. Oleh sebab itu dilakukan pengujian lagi dengan uji KolmogrovSmirnov dimana hasil uji menunjukkan besarnya nilai Kolmogrov-Smirnov adalah 0,594 lebih besar dari nilai signifikansi sebesar 0,05 maka dapat disimpulkan bahwa data penelitian adalah normal. \begin{tabular}{llr} 
Selanjutnya & \multicolumn{2}{c}{ dilakukan uji } \\
multikolinearitas. & Hasil pengujian
\end{tabular} multikolinearitas yang dilakukan pada kelima variabel independen (etika profesi, komitmen profesional, pengalaman kerja, independensi audit, fee audit) menghasilkan nilai tolerance lebih besar dari 0,10 dan nilai VIF lebih kecil dari 10 maka dapat disimpulkan bahwa di antar variabel independen tidak terjadi masalah multikolinearitas. Kemudian hasil uji heteroskedasitisitas menunjukkan bahwa titik-titik menyebar (tidak membentuk pola tertentu), menyebar di atas dan di bawah angka nol pada sumbu Y, maka dapat disimpulkan tidak terjadi masalah heteroskedastisitas. Selanjutnya dilakukan uji regresi untuk membuktikan hipotesishipotesi yang diajukan. Hasil uji hipotesis bisa dilihat pada tabel 2 berikut ini.

Tabel 2

Hasil Uji Hipotesis

\begin{tabular}{|l|l|l|l|l|l|}
\hline \multirow{2}{*}{\begin{tabular}{|l|l|l|l|} 
Unstandardized \\
Model
\end{tabular}} & $\begin{array}{l}\text { Standardized } \\
\text { Coefficients }\end{array}$ & & \\
\cline { 2 - 6 } & $\mathrm{B}$ & Std. Error & Beta & $\mathrm{T}$ & Sig. \\
\hline (Constant) & .191 & 5.076 & & .038 & .970 \\
etika profesi & .118 & .060 & .260 & 1.971 & .054 \\
komitmen profesional & .000 & .047 & .001 & .007 & .994 \\
pengalaman kerja & .333 & .156 & .273 & 2.137 & .037 \\
independensi audit & .049 & .058 & .117 & .845 & .402 \\
fee audit & .319 & .117 & .422 & 2.714 & .009 \\
\hline
\end{tabular}

a. Dependent Variable: pengambilan keputusan opini audit

Sumber : Data primer yang diolah, 2015 
Berdasarkan hasil pengujian menggunakan model regresi linear berganda ditunjukkan oleh persamaan sebagai berikut:

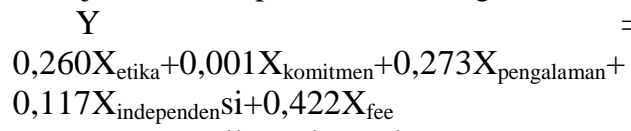

a. Pengujian Hipotesis Pertama

Hipotesis 1 : Etika profesi terhadap pengambilan keputusan untuk memberikan opini audit

Berdasarkan nilai koefisien regresi 0,260 dengan nilai $t$ hitung sebesar 1,971 dan nilai signifikansi sebesar 0,054. Oleh karena nilai signifikansi $>0,05$ sehingga $\mathbf{H}_{1}$ ditolak. Hal ini berarti bahwa etika profesi tidak berpengaruh terhadap pengambilan keputusan untuk memberikan opini audit.

b. Pengujian Hipotesis Kedua

Hipotesis 2: Komitmen profesi terhadap pengambilan keputusan untuk memberikan opini audit.

Berdasarkan nilai koefisien regresi sebesar 0,001 dengan nilai t hitung sebesar 0,007 dan nilai signifikansi sebesar 0,994. Karena nilai signifikansi $>0,05$ sehingga $\mathbf{H}_{2}$ ditolak. Hal ini berarti komitmen profesional tidak berpengaruh terhadap pengambilan keputusan untuk memberikan opini audit.

c. Pengujian Hipotesis Ketiga

Hipotesis 3 : Pengalaman Kerja terhadap pengambilan keputusan untuk memberikan opini audit.

Berdasarkan nilai koefisien regresi sebesar 0,273 dengan nilai t hitung sebesar 2,137 dan nilai signifikansi sebesar 0,037. Oleh karena nilai signifikansi $<0,05$ sehingga $\mathbf{H}_{3}$ diterima. Hal ini berarti bahwa pengalaman kerja berpengaruh terhadap pengambilan keputusan untuk memberikan opini audit

d. Pengujian Hipotesis Keempat

Hipotesis 4 : Independensi audit terhadap pengambilan keputusan untuk memberikan opini audit.

Berdasarkan nilai koefisien regresi sebesar 0,117 dengan nilai t hitung sebesar 0,845 dan nilai signifikansi sebesar 0,402. Oleh karena nilai signifikansi $>0,05$ sehingga $\mathbf{H}_{4}$ ditolak. Hal ini berarti bahwa independensi audit tidak berpengaruh terhadap pengambilan keputusan untuk memberikan opini audit.

e. Pengujian Hipotesis Kelima

Hipotesis 5: Fee audit terhadap pengambilan keputusan untuk memberikan opini audit.

Berdasarkan nilai koefisien regresi sebesar 0,422 dengan nilai t hitung sebesar 2,714 dan nilai signifikansi sebesar 0,005. Oleh karena nilai signifikansi $<0,05$ sehingga $\mathbf{H}_{5}$ diterima. Hal ini berarti bahwaf fee audit berpengaruh terhadap pengambilan keputusan untuk memberikan opini audit.

Tahap berikutnya adalah melakukan uji regresi berganda untuk menguji pengaruh semua variabel independen terhadap variabel dependen secara bersama-sama dan hasilnya bisa dilihat pada tabel 3 berikut ini.

Tabel 3

Hasil Uji F

ANOVA $^{b}$

\begin{tabular}{|ll|r|r|r|r|r|}
\hline Model & & Sum of Squares & Df & Mean Square & F & \multicolumn{1}{|c|}{ Sig. } \\
\hline 1 & Regression & 78.743 & 5 & 15.749 & 4.971 & $.001^{\mathrm{a}}$ \\
& Residual & 167.901 & 53 & 3.168 & & \\
& Total & 246.644 & 58 & & & \\
\hline
\end{tabular}

a. Predictors: (Constant), fee audit, etika profesi , pengalaman kerja, independensi audit, komitmen profesional

b. Dependent Variable: pengambilan keputusan opini audit 
Pada tabel 3 nilai signifikansi sebesar 0,001 atau lebih kecil dari 0,05 yang berarti signifikan. Hal ini berarti model regresi ini layak digunakan untuk mengetahui pengaruh variabel etika profesi, komitmen profesional, pengalaman kerja, independensi audit dan fee audit berpengaruh secara bersama-sama terhadap pengambilan keputusan untuk memberikan opini audit. Kemudian hasil koefisien determinasi pada riset ini dapat dilihat pada tabel 4 berikut.

Tabel 4

Hasil Koefisien Determinasi

\begin{abstract}
ilai
adjusted

$\mathrm{R}$ square

atau nilai

koefisien

determin

asi sebesar 0,255 atau 25,5\%, artinya bahwa etika profesi, komitmen profesional, pengalaman kerja, independensi audit dan fee audit mampu menjelaskan pengambilan keputusan untuk memberikan opini audit sebesar $25,5 \%$ an sisanya dijelaskan oleh variabel lain.
\end{abstract}

Model Summary

\section{PEMBAHASAN}

\section{Pengaruh Etika Profesi Terhadap Pengambilan Keputusan Untuk Memberikan Opini Audit}

Pengujian pengaruh pada variabel etika profesi terhadap pengambilan keputusan untuk memberikan opini audit dengan menggunakan data empiris dalam penelitian ini membuktikan bahwa etika profesi tidak berpengaruh terhadap pengambilan keputusan untuk memberikan opini audit. Pada penelitian sebagian responden adalah auditor junior, dimana auditor junior belum memiliki pengalaman yang tinggi sehingga etika profesionalnya belum sebik auditor yang senior. Pemahaman tentang etika profesi yang dimiliki oleh auditor junior dalam melaksanakan tugas belum cukup baik. Hasil penelitian ini mendukung penelitian Shabrina dan Indira (2011) dalam Rharasati dan Suputra (2014) yang menunjukkan hasil etika tidak berpengaruh terhadap ketepatan pemberian opini audit.

\section{Pengaruh Komitmen Profesional Terhadap Pengambilan Keputusan Untuk Memberikan Opini Audit}

Pengujia

pengaruh pada variabel komitme $\mathrm{n}$ profesional terhadap pengambilan keputusan untuk memberikan opini audit dengan menggunakan data empiris yang dilakukan dalam penelitian ini menunjukkan hasil komitmen profesional tidak berpengaruh terhadap pengambilan keputusan untuk memberikan opini audit. Komitmen terhadap suatu profesi akan berpengaruh terhadap pengambilan keputusan opini audit. Karena sebagian besar responden dalam penelitian ini aadalah auditor junior yang belum memilik komitmen profesional yang tinggi terhadap profesinya maka penelitian ini menghasilkan komitmen proesional yang tidak berpengaruh terhadap pengambilan keputusan untuk memberikan opini audit. Penelitian ini berbeda dengan penelitian Rharasati dan Suputra (2013) yang menunjukkan hasil komitmen profesional berpengaruh dan positif terhadap pengambilan keputusan untuk memberikan opini audit.

\section{Pengaruh Pengalaman Kerja Terhadap Pengambilan Keputusan Untuk Memberikan Opini Audit \\ Pengujian pengaruh pada variabel} pengalaman kerja terhadap pengambilan keputusan untuk memberikan opini audit dengan menggunakan data empiris yang dilakukan dalam penelitian ini menunjukkan hasil pengalaman kerja terbukti berpengaruh terhadap pengambilan keputusan untuk memberikan opini audit. Pengalaman merupakan suatu proses pembelajaran dan penambahan perkembangan potensi 
bertingkah laku baik. Secara teknis, semakin banyak tugas yang dikerjakan maka akan mengasah keahlian dalam mendeteksi suatu kesalahan dalam melakukan pekerjaaan audit. Seorang auditor yang memiliki pengalaman kerja di bidang auditing yang cukup lama memiliki pengetahuan yang lebih atas pekerjaannya sehingga mempengaruhi pengambilan keputusan untuk memberikan opini audit.

Penelitian ini mendukung penelitian Suraida (2005) dan Wijaya Kusuma (2011) menunjukkan hasil penelitian bahwa pengalaman kerja berpengaruh positif terhadap ketepatan pemberian opini. Dalam penelitian Rhararasati dan Suputra (2013) menunjukkan hasil bahwa pengalaman kerja berpengaruh positif terhadap pengambilan keputusan untuk memberikan opini audit.

\section{Pengaruh Independensi Audit Terhadap Pengambilan Keputusan Untuk Memberikan Opini Audit}

Pengujian pengaruh pada variabel independensi audit terhadap pengambilan keputusan untuk memberikan opini audit dengan menggunakan data empiris yang dilakukan dalam penelitian ini menunjukkan hasil independensi audit tidak berpengaruh terhadap pengambilan keputusan untuk memberikan opini audit. Independensi Audit berarti kejujuran diri auditor dalam perimbangkan fakta dan adanya pertimbangan objektif tidak memihak dalam diri auditor dalam merumuskan dan menyatakan pendapatnya, tidak dikendalikan oleh pihak lain dan tidak dapat dipengaruhi oleh pihak lain. Sikap independensi audit sangat dibutuhkan oleh seorang auditor.

Pada penelitian ini sebagian besar responden berusia < 30 tahun, maka sikap independensi yang dimiliki oleh seorang auditor masih lemah, sehingga mudah dipengaruhi oleh berbagai hal. Pendapat yang diberikan dalam pengambilan keputusan dalam memberikan opini audit cenderung tidak benar. Penelitian ini berbeda dengan penelitian sebelumnya yang menyatakan hasil berpengaruh positif dan signifikan dalam pengambilan keputusan untuk memberikan opini audit.

\section{Pengaruh Fee Audit Terhadap pengambilan Keputusan Untuk Memberikan Opini Audit \\ Pengujian pengaruh pada variabel} fee audit terhadap pengambilan keputusan untuk memberikan opini audit dengan menggunakan data empiris yang dilakukan dalam penelitian ini menunjukkan hasil fee audit berpengaruh terhadap pengambilan keputusan untuk memberikan opini audit. Fee audit dapat mempengaruhi seorang auditor dalam pengambilan keputusan untuk memberikan opini audit. Audit fee yang besar akan meningkatkan pengambilan keputusan untuk memberikan opini audit. Besaran fee yang diterima oleh kantor akuntan publik berpengaruh terhadap pengambilan keputusan untuk memberikan opini audit. Semakin besar fee audit yang diterima oleh auditor maka pekerjaan atau tugas yang diberikan akan dikerjakan dengan sungguh-sungguh.

Hal ini didukung oleh Hoitash et al (2007) dalam Pratistha dan Widhiyani (2014), menemukan bukti bahwa ketika auditor melakukan negosiasi dengan pihak manajemen mengenai besaran tarif fee yang dibayarkan terkait hasil kerja laporan auditan. Sehingga penelitian ini menunjukkan hasil fee audit berpengaruh terhadap pengambilan keputusan untuk memberikan opini audit.

\section{KESIMPULAN}

Berdasarkan pada data yang telah dikumpulkan dan pengujian yang telah dilakukan terhadap permasalahan dengan menggunakan model regresi berganda, maka dapat diambil kesimpulan sebagai berikut:

1. Etika profesi tidak berpengaruh terhadap pengambilan keputusan untuk memberikan opini audit.

2. Komitmen profesional tidak berpengaruh terhadap pengambilan keputusan untuk memberikan opini audit.

3. Pengalaman kerja berpengaruh terhadap pengambilan keputusan untuk memberikan opini audit.

4. Independensi audit tidak berpengaruh terhadap pengambilan keputusan untuk memberikan opini audit. 
5. Fee audit berpengaruh terhadap pengambilan keputusan untuk memberikan opini audit.

Saran

1. KAP memberikan pelatihan atau seminar kepada auditor junior agar auditor lebih baik lagi dalam melakukan audit laporan keuangan.

2. Manajemen memberikan motivasi dan dorongan kepada para auditornya untuk berani mengungkapkan temuan-temuan.

\section{Keterbatasan Penelitian}

1. Karena ada gangguan uji asumsi klasik model menunjukkan homoskedastisitas maka hasil uji $\mathrm{F}$ cenderung bias.

2. Kuesioner tentang pengambilan keputusan belum mampu mempresentasikan bagian proses pengambilan keputusan untuk memberikan opini audit.

3. Pengukuran pengalaman kerja dalam kuesioner belum mampu mengukur langsung variabel tersebut.

4. Pada penelitian ini sebagian responden yang berpartisipasi adalah auditor junior karena auditor junior belum memiliki pengalaman dan pengetahuan untuk melaksanakan tugas sehingga besar kemungkinan melakukan kesalahan dalam mengaudit laporan keuangan.

5. Penelitian ini dilakukan pada saat auditor sibuk sehingga banyak kantor akuntan publik yang tidak mengisi kuesioner.

\section{Agenda Penelitian Mendatang}

Penelitian ini di masa mendatang diharapkan dapat menyajikan hasil penelitian yang lebih berkualitas lagi beberapa hal diantaranya:

1. Penelitian lebih lanjut disarankan untuk menambah variabel-variabel yang berpengaruh terhadap pengambilan keputusan untuk memberikan opini audit, dimana pengambilan keputusan untuk memberikan opini audit dapat dipengaruhi oleh beberapa factor lain, seperti motivasi kerja.

2. Penelitian lebih lanjut diharapkan dapat memperluas daerah survey sehingga hasil penelitian lebih mungkin untuk disimpulkan secara lebih lengkap, serta diharapkan dapat memfokuskan penelitian pada grup tertentu, misalnya untuk senior auditor, supervisor, dan manajer, yang memiliki tingkat pendidikan minimum $\mathrm{S} 1$ dan pengalaman bekerja sebagai auditor lebih dari 3 tahun, khususnya dalam penelitian mengenai pengambilan keputusan untuk memberikan opini audit.

3. Penelitian selanjutnya disarankan untuk menambah sampel penelitian yang lebih banyak agar lebih mendapatkan gambaran keadaan secara lebih luas dari objek yang diteliti.

\section{DAFTAR PUSTAKA}

Boynton, William C, Raymond N. Johnson, Walter G. Kell. 2002. Modern Auditing. Jilid 1 Edisi Ketujuh. Jakarta: Erlangga.

Kasidi. 2007. Faktor-Faktor Yang Mempengaruhi Independensi Auditor Persepsi Manajer Keuangan Perusahaan Manufaktur Di Jawa Tengah. Tesis. Program Studi Magister Sains Akuntansi Program Pascasarjana Universitas Diponegoro. Semarang.

Ghozali, Imam. 2009. Aplikasi Analisis Multivariate Dengan Program SPSS. Semarang: Badan Penerbit Universitas Diponegoro.

Mayangsari, Sekar. 2003. Pengaruh Keahlian Audit dan Independensi terhadap Pendapat Audit: Sebuah Kuasieksperimen. Jurnl Riset Akuntansi Indonesia, 6(1):h:1-22.

Swari Mitha, I. A. Putu Candra dan I. Wayan Ramantha. 2013. Pengaruh Independensi dan Tiga Kecerdasan Terhadap Pertimbangan Pemberian Opini Auditor. E-Jurnal Akuntansi 
Universitas Udayana 4.3: 489508.

Pratistha, K. Dwiyani dan Ni Luh Sari Widhiyani. 2014. Pengaruh Independensi Auditor Dan Besaran Fee Audit Terhadap Kualitas Proses Audit. E-Jurnal Akuntansi Universitas Udayana 6 (3):419-428.

Pratiwi, Astari Bunga dan Indira Januarti. 2013. Pengaruh Faktor-Faktor Skeptisisme Profesional Auditor Terhadap Pemberian Opini (Studi Empiris Pada Pemeriksa BPK RI Provinsi Jawa Tengah). Diponegoro Journal of Accounting, 2(1):h:1-14.

Purwanti, Meilani dan Sumartono. 2014. Pengaruh Kompetensi dan Independensi Auditor Terhadap Efektivitas Proses audit Serta Dampaknya Pada Ketepatan Pemberian Opini Akuntan Publik. Study \& Accounting Research, Vol XI, No.1.

Rharasati, A.A. Istri Dewi dan I. D. G. Dharma Suputra. 2013. Faktor-Faktor Yang Mempengaruhi Auditor Dalam Pengambilan Keputusan Untuk Memberikan Opini Audit. E-Jurnal Akuntansi Universitas Udayana 3.3: 147-162.

Siregar, Siky Raditya. 2012. Faktor-Faktor Yang Mempengaruhi Pertimbangan Opini Audit Atas Laporan Keuangan Pemerintah Daerah Istimewa Yogyakarta. Accounting Analysis Journal 1(2).

Sukmawati, Ni Luh Gede, Nyoman Trisna Herawati, Ni Kadek Sinarwati. 2014. Pengaruh Etika Profesi, Kecerdasan Intelektual, Kecerdasan Emosional, Dan Kecerdasan Spiritual Terhadap Opini Auditor (Studi Empiris Pada Kantor Akuntan Publik Wilayah Bali). E-Journal S1 Akuntansi Universitas Pendidikan Ganesha (Vol:2 No:1).

Zu'amah, Surroh. 2009. Independensi Dan Kompetensi AuditorPada opini Audit
(Studi BPKP Jateng). Jurnal Dinamika Akuntansi, 1(2), pp. 145-154.

http://wap.panturanews.com. Disoal, APBD

Disclaimer Opinion Berubah Jadi WDP. Diakses Kamis, 07 Juni 2012. 